\title{
Our successful surgical approach in a giant vegetative mass diagnosed on aortic valve
}

\author{
A Gurbuz*, U Yetkin, I Yurekli, I Peker \\ From 23rd World Congress of the World Society of Cardio-Thoracic Surgeons \\ Split, Croatia. 12-15 September 2013
}

\section{Background}

Cardiac complications of infective endocarditis occur via vegetations on heart valves.

\section{Method}

Our case was a 46-year-old female. She was suffering from shortness of breath for one week increasing in intensity. Transesophageal echocardiography revealed moderate aortic regurgitation and a hypermobile mass of $15 \times 20 \mathrm{~mm}$ with hyper- and hypoechoic densities sitting on all leaflets of the aortic valve moving in and out of the left ventricular outflow tract. She was hospitalized for an emergency operation. Her past medical history was significant for a severe upper respiratory tract infection 4 months ago.

\section{Results}

After a median sternotomy and standard cannulation, an aortotomy incision was done. A giant vegetative mass was expanding from beneath non-coronary cusp to the anterior leaflet of mitral valve, probably due to late endocarditis. This broad based vegetation was totally extirpated. Due to severe destruction of the aortic valve, it was completely excised. Then, valve replacement with $21 \mathrm{~mm}$ St. Jude bioprosthetic valve was performed. Early postoperative period was event-free. After consulting with Department of Infectious Diseases she was discharged with oral antibiotic regimen. Her late postoperative outpatient follow-up continues.

\section{Conclusion}

Intracardiac injury develops more severely if the diagnosis of native valve endocarditis is delayed or if the etiological agents are more virulent and resistant to antibiotherapy.

Izmir Katip Celebi University Ataturk Training and Research Hospital, Department of Cardiovascular Surgery, Turkey
Surgical therapy becomes more widely used. Surgery may even be required in $20-40 \%$ of patients after recovery from infective endocarditis.

Published: 11 September 2013

\section{doi:10.1186/1749-8090-8-S1-P14}

Cite this article as: Gurbuz et al:: Our successful surgical approach in a giant vegetative mass diagnosed on aortic valve. Journal of Cardiothoracic Surgery 2013 8(Suppl 1):P14.
Submit your next manuscript to BioMed Central and take full advantage of:

- Convenient online submission

- Thorough peer review

- No space constraints or color figure charges

- Immediate publication on acceptance

- Inclusion in PubMed, CAS, Scopus and Google Scholar

- Research which is freely available for redistribution
C Biomed Central 